\title{
Frederik Tygstrup
}

\section{Den litterære by}

Mellem system og sansning

\section{Storbyreproesentation}

Selv det mest overfladiske overblik over det tidlige tyvende århundredes roman vil bemærke, hvordan en påfaldende del af disse værker er intimt knyttet til et billede af byen og en forestilling om byen: vi taler uden videre om Marcel Prousts Paris, James Joyces Dublin, Robert Musils Wien, Franz Kafkas Prag, Alfred Döblins Berlin, Virginia Woolfs London, John Dos Passos' New York, Alexander Belys Petersborg, og så videre.

Franco Moretti ${ }^{1}$ har gjort opmærksom på, at romanen i sin storhedstid, i det nittende århundrede, var intimt knyttet til forestillingen om nationalstaten, og at det var denne, der udgjorde romanens egentlige rum, fysisk såvel som forestillingsmæssigt. I dette rum indgår byen naturligvis som et (ofte betydningsfuldt) element, men netop kun som et element, som en hovedstad, der kroner nationalstatens organisme. Det nittende århundredes romanhelte var franskmænd, russere, englændere, østrigere eller tyskere. Deres efterkommere, derimod, bor ikke i hovedstæder, men i metropoler i al almindelighed; og disse metropoler optræder ikke længere som kvintessensen af en given national organisme, men udgør organismer for sig, hele universer, som ofte endda påkalder sig mindre interesse som særlige byer end som storbyer overhovedet. Gennem denne relation til storbyen ophører romanen, som Moretti også har bemærket, med at være nationallitteratur og bliver i stedet verdenslitteratur. Det litterære verdenskort består ikke længere af nationalstater, der hver især er kendetegnet ved et bestemt forhold mellem by og land - eller mellem hoved og krop, for at blive i billedet - men af et system af metropoler, der har en tættere indbyrdes relation, end de hver især har med deres nationale bagland, og af et tilsvarende antal af ikke-bymæssige steder, hvis primære kendetegn ikke længere er at være bagland, men snarere at være noget tilbagestående, noget endnu-ikke urbaniseret. Hos Balzac kan man stadig finde billeder af den rurale produktion som forudsætning for den urbane cirkulation, mens landet i de første moderne storbyromaner snarere står i regressionens end i produktionens billede. 
Alt dette er knap nok litteraturhistorie, men bare historie, en stærkt stiliseret version af historien om udviklingen af forholdet mellem land og by op igennem det nittende århundrede. Der er imidlertid to mere specifikke litteraturhistoriske pointer, der byder sig til i forlængelse af denne almene historik. Den første vedrører den påfaldende massive storby-tematik i 20'ernes og 30'ernes roman, som næppe er overgået hverken før eller siden, mens den anden vedrører en række mere tekniske forhold omkring storbyrepræsentationen i den moderne roman og sammenhængen mellem storbyrepræsentation og romanens formelle udvikling.

Der synes at eksistere en fælles erfaring for den store generation af modernistiske romanforfattere, som danner grundlag for deres mere eller mindre unisone tematisering af storbyen, som om byen og livet $i$ byen pludselig påkaldte sig en intens opmærksomhed. Det ville imidlertid formentlig være upræcist at lokalisere denne erfaring direkte til urbaniseringsfænomenet som sådan, til en voldsom byudvikling netop i denne periode; det kunne få en til at overse både de lokale forskelle og det lange historiske perspektiv, en hel epokes erfaring af, at »en bys form forandres hastigere end en dødeligs hjerte«. Den fælles erfaring består snarere i en historisk reorganisering af måden at tænke byen, livet $\mathrm{i}$ byen og dens forhold til sịne omgivelser på. Raymond Williams bemærker et sted i The Country and the City: »det almindelige billede af landet er i dag et billede af fortiden, og det almindelige billede af byen et billede af fremtiden. $\ll^{2}$ Williams diagnosticerer hermed en ændret mental geografi, som han ganske vist er kritisk overfor, fordi den gør sig blind for udviklingsperspektivet netop i relationen mellem land og by, men som, tror jeg, ganske godt rammer den store modernistiske generations forhold til byen. For denne generation præsenterer byen sig ikke som en del af en sammenhæng, en traditionaliseret verden, hvor der faktisk eksisterer et udviklingsperspektiv i udvekslingen mellem by og land. Efter Første Verdenskrig, den gamle verdens sammenbrud og fornemmelsen af at være vidne, ikke til nationalstaternes, men hele verdens historie, er fremtiden for denne generation allerede begyndt. De er, for at variere Paludan, snublet ind $\mathrm{i}$ det tyvende århundrede. Og når de vil fors $\emptyset$ ge at finde deres ben igen, planter de dem uden tøven $i$ et storbyunivers. Ikke for at indtage en plads i rummet, men først og fremmest for at finde en plads i tiden. Forfatterne giver sig til at indtage de gamle storbyer og gør dem til centrum for deres udforskning af den fremtid, som de føler de lever i. Byerne bliver be-tænkelige, bliver en opgave, som de må forholde sig til. Det betyder ikke, at de byer, som de møder og sætter sig for at give et billede af, nødvendigvis har forandret sig voldsomt netop da, de kan blot ikke længere få dem til at falde på plads i den mentale geografi, som de har arvet fra deres barndoms nittende århundrede. Når byen bliver det centrale motiv for en hel 
generation af romanforfattere, er det således måske ikke, fordi de pludselig opdager byen, men snarere fordi de mister den, mister det gamle mentale landkort og står tilbage midt i en by, som de ikke længere rigtig ved, hvad de skal stille op med. Raymond Williams siger det udmærket; efter at have konstateret den ny måde, landet og byen placeres i bevidstheden på som tilhørende henholdsvis fortiden og fremtiden, fortsætter han: »That leaves, if we isolate them, an undefined present.«

De modernistiske romanforfatteres livtag med byen er et forsøg på at forholde sig til og fremstille den by, der er nærværende omkring dem, ud fra en ny horisont, dvs. på at finde en såvel refleksiv som sanselig definition af byens »undefined present«. Men hvordan bære sig ad med at forholde sig reflekterende til byen med romanforfatterens praksis? Dette spørgsmål rejser den anden problemstilling, jeg nævnte før: sammenhængen mellem storbyrepræsentation og den formelle eller æstetiske udvikling i den modernistiske roman.

Volker Klotz har i en vigtig bog fra 1969, Die erzählte Stadt, afsøgt et antal byfremstillinger $i$ romanens historie fra det tidlige attende til det tidlige tyvende århundrede ud fra en tese om, at romanen med sin løse æstetiske struktur, muligheden for at afsøge flere parallelle og ofte indbyrdes modstridende tidslige, rumlige og mentale universer, snarest har fundet sin ideale genstand i byen. Det gælder for byen såvel som for romanen, siger Klotz, at de begge »er ikke blot udtryk, men også, takket være deres systemkarakter, en formende organisation af den prosaiske verden ${ }^{3}{ }^{3}$ Inden for dette meget generelt opfattede fællesskab (som jeg i en anden forbindelse skal vende tilbage til om lidt) gør Klotz opmærksom på en række historiske differentieringer og udviklingslinier, forskellige måder at lægge roman-byer til rette på.

I en kritisk kommentar til Volker Klotz gør en anden storbylitteraturhistoriker, Klaus Scherpe, imidlertid opmærksom på en grundlæggende differentiering, som der ikke er plads til inden for Klotz' begrebsapparat, men som er afgørende for forståelsen af det tyvende århundredes storbyromaner, nemlig mellem hvad han kalder det attende og nittende århundredes »fortalte byer« og det tyvende århundredes »byfortællinger $«{ }^{4}$ Kort fortalt går denne forskel på, hvordan byfremstillingen hænger sammen med det narrative projekt, som de enkelte romaner artikulerer. I den traditionelle romantype præsenteres byen gerne inden for rammerne af en handling, som er centreret om en subjektiv skæbne, udfoldet $i$ et kontinuert tids-rum gennem en række indbyrdes motiverede begivenheder, hvor byen enten er miljø for en del af en handling eller (nok så ofte) bliver et sted, hvor handlingstråde, ambitioner og projekter går til grunde. Den fortalte by bliver en kompliceret topografi, hvor handlingssekvenser krydser hinanden, eller hvor de enkelte agerende romanpersoners ek- 
sistentielle projekter ligefrem går til grunde i det uoverskuelige system af antagonistiske projekter, - man kan se begge dele hos Balzac.

Hvis romanen og byen, som Klotz argumenterer, er konsubstantielle, omfatter dette fællesskab imidlertid også en grundlæggende antagonisme mellem fortællingens ideale linearitet og byens labyrintiske kompleksitet. Romanen kan rumme og gengive denne kompleksitet, men særligt det nittende århundredes roman vidner også om en slags ideologisk spænding mellem kompleksitet og linearitet, som slår sig ned i formen og typisk gør storbyromanerne til desillusionsromaner og storbyen til desillusionens sted: dér, hvor den unge mands illusioner, som afgiver den narrative struktur, lider skibbrud. I denne forstand lever den fortalte by på nåde i det nittende århundredes roman som en anomali i det univers, den fortællende gestus forudsætter.

Overgangen fra den fortalte by til byfortællingen opstår da, hvor byen ikke længere repræsenteres, hvis man kan sige det så primitivt, med præ-urbane kunstmidler. Her sættes elementer af storbyerfaringen direkte igennem i fremstillingsmåden, således at diskontinuitet, forøget hastighed, afindividualisering, tilfældige og abrupte kollisioner mellem ting og anliggender, den komplekse interaktion mellem forskelligartede og hinanden overlejrende diskursive og fysiske systemer, og så videre, nu afgiver de formelle principper for fremstillingen.

Udgangspunktet for de modernistiske byromaner er således i en vis forstand, at byens virkelighed slet ikke længere kan repræsenteres, eftersom den modsætter sig de overleverede repræsentationsmåder. Storbyen som »undefined present« rummer dermed en dobbelt udfordring: på den ene side en udfordring til den litterære teknik, et krav om at opfinde fremstillingsmåder, der kan indfange det væsentligt bymæssige, og på den anden side, som en skærpelse heraf, en udfordring til tanken: hvordan overhovedet tænke byen, hvordan udvinde mønstre af dens mangfoldige impulser til sanserne og til intellektet, der kan sætte os i stand til at gøre os en forestilling om byen og om det, som livet i byen $g \varnothing r$ ved menneskelivet.

\section{Den fanomenologiske horisont}

Dette vældig ambitiøse krav til en moderne repræsentation af storbyen, at den i samme gestus må opfinde teknikker til at fremstille byen og måder overhovedet at tænke byen på, stammer fra romanerne selv. De deler alle mere eller mindre eksplicit en grundlæggende antagelse af, at vi endnu ikke ved, hvordan storbyens »udefinerede nærvær « kan begribes. Derfor bliver repræsentationen af byen tillige et epistemologisk ærinde. Romanerne tænker byen; hvilket $\mathrm{i}$ 
næste omgang stiller krav til, hvordan vi skal læse dem. Vi må forstå repræsentationen som andet og mere end et spørgsmål om reference, dvs. aspekter af den fortale by. Ikke bare en fremstilling af byen, men en konstruktion af byen, opfindelsen af en særlig fiktionstype - byfortællingen - der tænker og fremstiller i samme gestus.

Den væsentlige opgave i studiet af den litterære repræsentation af byen er i denne henseende at finde nogle læsemåder, der kan holde disse to aspekter i byfortællingen sammen. Den største fare, der lurer på et sådant projekt, er at gøre de litterære værker til blotte vidnesbyrd om en historisk forandring af bylivet. Den sociologiske annotering af den modernistiske storbylitteratur ligger lige for: her får vi et direkte, formelt formidlet udtryk for storbyens anonymisering af enkeltindividerne (tænk på fortælleren i Rilkes Malte Laurids Brigge), sanseindtrykkenes fragmentering (Franz Biberkopf i linie 41 til Alexanderplatz), abstraktionen af sociale relationer, massificeringen og dens erstatning af subjektive med kollektive handlemåder (de overindividuelle bevægelsesmønstre i åbningskapitlet til Manden uden egenskaber), den abrupte og sammenhængsløse kommunikation (avisoverskrifterne og reklameskiltene hos Dos Passos) - og så videre.

Alle disse iagttagelser er naturligvis gyldige nok (eller rettere: det er en oplagt opgave at unders $\emptyset$ ge deres gyldighed); romanerne udgør, som Michel de Certeau siger, en exceptionel zoologisk have af måder at opleve og iagttage storbyen på..$^{5}$ Men for at honorere den kunstneriske ambition, der er nedlagt $\mathrm{i}$ romanerne, må vi også spørge os, hvordan disse måder at opleve og iagttage byen på kan lære os at tænke byen - at vide, at vi ikke er færdige med at tænke over byen, når vi har foretaget annoteringen, men at vi først derefter står over for at forstå, hvordan oplevelsen og iagttagelsen, sådan som de gennemføres i teksterne, er en måde at tænke på.

Forståelse af storbytematikkens epistemologiske indhold må derfor tage udgangspunkt i en konkret kortlægning af de måder, den storbyspecifikke sanseoplevelse objektiveres $i$ den litterære form. Sartre har $\mathrm{i} » \mathrm{Qu}$ 'est-ce que la littérature? « på anskuelig vis skematiseret forholdet mellem sansning og formning i en skitse over den litterære repræsentations fænomenologiske aspekter. Det første trin heri er en perception, mit møde med en given genstandslig verden, hvor jeg syntetiserer en rakke sanseindtryk i et indre billede: »un objet fait âme«. Det andet trin er en konstruktion, hvor jeg gennem den litterære teknik genskaber, ikke den virkelighed, som jeg sansede, men det intentionelle billede, som jeg med fantasiens hjælp etablerede, dvs. "une âme faite objet «."

Den litterære genstand er en symbolisering af en symbolisering af en bestemt genstandsverden. At der for en fænomenologisk betragtning således er tre led at holde $\varnothing j e$ med $\mathrm{i}$ den litterære repræsentation er naturligvis forholds- 
vis banalt; det er ikke i sig selv opsigtsvækkende, at vi i den litterære form ikke har at gøre med en umiddelbar reference, at vi ikke har direkte adgang til et sagsforhold gennem repræsentationen. Netop i denne sammenhæng, hvor talen er om storbyrepræsentation, er det imidlertid, tror jeg, umagen værd at spørge sig, hvad for en slags genstand det overhovedet er, repræsentationen har med at gøre; »byen« er dog ikke et simpelt fænomenologisk æbletræ. Denne side skal jeg komme tilbage til om lidt.

Hvad angår det andet led, formidlingen af det intentionelle fantasibillede $i$ den litterære objektivering, kan det være nyttigt igen at fastholde den diskontinuitet, der er involveret i repræsentationen, dvs. det forhold, at den billeddannelse, som udfoldes i den litterære tekst, ikke betegner en perception, men derimod objektiverer den. Gilles Deleuze har foreslået en begrebsbrug, der tydeliggør dette; det, som skabes i kunsten, siger han, er percepter: kunsten kan have udgangspunkt $i$ en sansning, den kan skabe en sansning, men altid kun en sansning, som er objektiveret i det kunstneriske materiale. »Kunsten hensigt er gennem det æstetiske materiale at frigøre et percept fra perceptionen af en genstand og fra det perciperende subjekts tilstand. ${ }^{7}$ Når der er grund til at bemærke denne æstetiske »objektivisme«, er det for at understrege, at vi ikke læser »om« sansninger og emotioner. Kunsten opfinder mulige sansninger og emotioner gennem sine percepter og affekter. Og disse rummer præcis romanforfatternes bidrag til at tænke byen; de giver os forskellige aspekter og modeller, et antal variationer over en storbyerfaring; Rilkes og Joyces lyd-percepter, Musils bevægelsespercepter, Prousts feticherede og synekdokiske percepter (brostenene i Guermantes' gård), alt dette bogføres og forbindes i næste omgang med karakteristiske affekter, en stilhed, som associeres med lyd-perceptet, en stilstand, som associeres med bevægelsesperceptet, - en række objektiverede mentale tilstande, som vokser frem af bylivet.

Den metodiske fastholdelse af, at studiet af den litterære by må tage udgangspunkt i de konkrete billeder af sansningen, som romanerne er komponeret af - at kunsten tænker gennem opfindelse af sansninger - belyser imidlertid ikke umiddelbart det spørgsmål, som jeg rejste ovenfor, nemlig karakteren af storbyen som fænomenologisk genștand. Dette spørgsmål kompliceres af, at der ikke findes noget »naturligt « intentionelt leje for betragtningen og fremstillingen af et storbyunivers; spørgsmålet om konstitutionen af den intenderede genstand er allerede, ved vi fra Merleau-Ponty, uhyre kompliceret, når det drejer sig om Montagne Ste. Victoire, men den er fortvivlende meget mere kompliceret, når det drejer sig om Paris. Byen er en form, der viser sig for sansningen og bevidsthedens intentionelle kategorier, men den er også en formning af sansningen og bevidsthedskategorierne. ${ }^{8}$ Derfor kan den betragtes både som en objektiv ting og som en praksis, eller rettere: som begge dele på 
samme tid. Således tenderer de fleste nyere beskrivelser af byen da også mod det systemiske, en funktionssammenhæng, hvor det ikke giver mening at sondre alt for skarpt mellem objektsiden og praksissiden; billederne er legio: system, fabrik, organisme, maskine... Som fænomenologisk genstand tager byen skikkelse af et system, der organiserer det faste og det variable, det manifeste og det tænkelige, på en sådan måde, at disse - for en traditionel fænomenologi skarpt adskilte - eksistensmåder føjer sig sammen til en ny type af objektivitet. Det er dette beskrivelseslag, Musil er på sporet af, når han ligner byen med »en kogende blære, som hviler i et fad bestående af det konstante stof af huse, love, anordninger og historiske overleveringer«.

Det er et gennemgående træk i den modernistiske storbylitteratur, at den rummer en skærpet opmærksomhed på byens fænomenologiske ufremstillelighed; at ønsket om at undvige de overleverede opfattelses- og fremstillingsmåder for at nå frem til sagen ikke har bragt »sagen « selv for en dag, men nok netop vanskeligheden ved at sammenfatte sagen, og dermed også har igangsat en sammenbidt bestræbelse på at konstruere beskrivelsesmåder og -perspektiver, der kan indfange væsentlige aspekter af det bymæssige.

Hermed fremtræder et andet vigtigt fælles kendetegn ved den fiktionstype, som disse romaner konstruerer, nemlig bestræbelsen på at fremstille nogle af de systemisk-funktionelle sammenhænge, som karakteriserer byen. Meget af den umiddelbare »besynderlighed « $\mathrm{i}$ deres udtryk, som ofte for let er blevet affærdiget som modernistisk formeksperiment, skriver sig tilbage til denne ambition, netop fordi fokuseringen på sådanne funktioner gerne bryder med repræsentationens »normalindstillinger«. Greb, som forekommer »paralogiske« - når Musil negligerer forskellen mellem res extensa og res cogitans ved at sætte forodninger og traditioner på linie med huse og gader, når Joyce kombinerer den mest intime stream-of-consciousness med ryggesløs polyfoni, når Dos Passos gør personlige motiver udskiftelige mellem forskellige personer, når Virginia Woolf panorerer rundt $\mathrm{i}$ Londons gader, ikke via en person, som bevæger sig, men mellem forskellige personer på forskellige poster, osv . - alle sådanne greb signalerer, at fokus for det, som fremstilles, det intenderede, ikke nødvendigvis befinder sig på det fortrolighedsplan, vi umiddelbart forventer, men netop på et systemisk niveau, som ikke nødvendigvis er abstraheret eller fortænkt og uanskueligt, men blot udgør en objektivitet, som der ikke findes vante fremstillingsformer til at repræsentere. Alle de komplicerede kompositionsmønstre, som disse værker rummer, og som fortolkningstraditionen har måttet fortabe sig i, parallelismer, gentagelser, kontrapunkter, inversioner, alle disse musikalske greb, kan - tror jeg - læses som bidrag til en sådan systemisk-funktionel beskrivelsesstrategi, som objektiveres i fiktionen. 


\section{System og sansning}

Denne læsemåde kan forekomme umiddelbart at stå i modstrid med den meget konkrete læsning, som jeg slog til lyd for ovenfor, det abstrakte system over for den objektiverede sansning. Denne modstrid er imidlertid, mener jeg, kun tilsyneladende, og spændingen mellem de to sider bør forstås, ikke som et teoretisk problem, men præcis som det sted, hvor den modernistiske storbylitteratur har sin største artikulationskraft, der, hvor den aller mest tydeligt kan bidrage til at tænke byen med æstetiske midler. Sammenhængen mellem de to sider giver sig allerede ud fra Sartres fænomenologiske model, hvor den første relation, dannelsen af det intentionelle billede, som antydet netop rummer den problematik, der fører til etableringen af de systemiske billeder, mens den anden relation, spørgsmålet om at indskrive den sanselige stimulus og/eller reaktion i det æstetiske materiale, om at konstruere et percept eller en affekt, ikke er et helt andet projekt, men tværtimod en prøvesten for, om det overhovedet vil lykkes at skabe et kunstnerisk udtryk ud fra det systemiske billede af byen. Jeg vil derfor fors $\emptyset$ ge at antyde en af de måder, hvorpå sammenhængen mellem de to sider etableres i byfortællingen.

I almindelighed vil det formentlig næppe være kontroversielt at bemærke, at de to træk, som umiddelbart påkalder sig størst opmærksomhed i de modernistiske byfortællinger, er vægten på den umiddelbare sansning og de komplicerede kompositionelle storformer. I forlængelse af Walter Benjamins bemærkninger om chokberedskabet er det da også ligetil at se sammenhængen mellem storbyerfaringen med dens overskud af sanseindtryk, som bevidstheden bombarderes med, og den fremstillingsform, som mimer enhver bevidstheds (og enhver fremstillings) besvær med at holde trit med sansningen; dette princip afsløres allerede en side inde i Döblins Berlin Alexanderplatz:

»Vrimmel, sikken en Vrimmel. Hvor det bevægede sig. Der er ikke mere en sund Tanke i min Hjerne, den er tørret ganske ind. Hvad var det alt sammen. Skotøjsforretninger, Hatteforretninger, Glødelamper, Knejper. Folk må jo da have sko, naar de løber saadan omkring, vi lavede jo ogsaa sko, det maa jeg prøve at holde fast paa. Hundrede blanke Ruder, lad dem dog blinke, de vil alligevel ikke gøre dig bange, du kan jo slaa dem i smadder, hvad er der nu med dem, de er jo bare nypolerede «?

- og så videre. Eller tag Musils beskrivelse af Grev Leinsdorffs køreheste på en tur gennem Wien: 
»Pepi og Hans var veltilkørte heste; de strakte ud og slog med hovene mod den solbeskinnede, husindrammede gade; for dem var menneskene en grå vrimmel, der hverken beredte dem glæde eller skræk: butikkernes brogede udstillinger, kvinderne, der prangede i lysende farver - marklodder, der ikke kan nydes; hattene, slipsene, bøgerne, brillanterne langs gaden: en ørken. Kun de to drømme- øer: stald og trav, hævede sig op over det hele, og undertiden forskrækkedes Pepi og Hans ligesom i drømme eller leg for en skygge og trykkede sig op ad vognstangen, men lod sig atter pacificere af et fladt piskeslag og lagde sig taknemmeligt $\mathrm{i}$ selen ${ }^{10}$

Et af de mest gennemgående træk $\mathrm{i}$ disse romaner er deres interesse for perceptionsmåder og besværet med at få den bymæssige perception til at stemme overens med de overleverede anskuelses- eller kognitionsmåder, og en stor del af det kunstneriske arbejde, som er nedlagt $\mathrm{i}$ dem, er investeret $\mathrm{i}$ at konstruere adækvate percepter.

Men samtidig rummer de den tendens til »abstraktion«, som man vist plejer at sige, og som jeg har foreslået at betragte, netop ikke som abstraktion, men som et forsøg på at stille ind på en anden type af genstandsligheder, byens system-fænomenologi, som man kunne nævne adskillige flere eksempler på end dem, jeg allerede kort har berørt.

Det virkelige bidrag til at tænke byen i den æstetiske form ligger imidlertid ikke alene $\mathrm{i}$ disse to tendenser hver for sig, men i det bestandige fors $\emptyset \mathrm{g}$ på at få sansning og »abstraktion « (for nu af lethedsgrunde at bibeholde dette traditionelle, omend ikke særlig præcise udtryk) til at mødes. De kan betragtes hver for sig som fremstillingsstrategier, men netop disse romaners kraft til at tænke byen viser sig klarest i de tilfælde, hvor sansningen kobler sig direkte på det systemiske, hvor et bestemt system-aspekt, som fremtræeder i de formelle modeller, udkrystalliserer sig i en sansning, i hvad man kunne kalde et systempercept.

Musil afslører denne ambition i det berømte indledningskapitel til Manden uden egenskaber - et par sider, hvis eminente eksposition af storbyfremstillingens problemstillinger ville kunne udfoldes meget langt - $\mathrm{i}$ den bevægelsesdynamiske beskrivelse af byens gangart:

»Biler susede fra smalle, dybe gader ud på lyse, flade pladser. Fodgængermørke dannede skyagtige snore. Hvor kraftigere fartstreger kørte tværs gennem deres løse hast tyknede de, rislede siden hurtigere og havde efter fă svingninger deres regelmæssige puls igen. Hundreder af toner var tvundet sammen til en trådet st $\varnothing \mathrm{j}$, hvorfra enkelte spidser ragede 
frem, langs hvilken skarpe kanter løb og atter udjævnedes, hvorfra klare toner skilte sig ud og flagrede bort. Skønt støjens særpræg ikke var til at beskrive, ville et menneske, selv efter årelang fraværelse, med lukkede øjne kunne høre på den, at han befandt sig i rigshoved- og residensstaden Wien. (...) Som alle store byer bestod den af uregelmæssighed, skiften, fremadgliden, ikkeholdentrit, sammenst $ø$ d af ting og anliggender, derimellem bundløse punkter af stilhed, af baner og ubanet, af et stort rytmisk slag og den evige forstemning og forskydning af alle rytmer mod hinanden $(. ..) \ll$

Et af de første træk, der springer i øjnene i denne bybeskrivelse, er det bemærkelsesværdige beskrivelsesniveau, som Musil anlægger i den abstraherende fremstilling af bevægelsens dynamik. Det fænomen, som han fokuserer på, er hverken en simpelt eksisterende ting på linie med f.eks. byen som en objektiv topografi, der udstikker mulige bevægelsesruter for byens menneskemasser, eller en subjektiv virkelighed, der henviser til en en bestemt bevidsthedstilstand hos et enkeltindivid i massen. Musil synes at forkaste denne traditionelle modstilling mellem det individuelle på den ene side og den materielle ramme for dets handlinger i rummet på den anden og udkaster i stedet en slags vektordiagram for et totalt bevægelsesmønster og den proces, hvorigennem alle bevægelser integreres i et stabilt, enhedsligt system. Dette diagram fremstilles som et virkeligt fænomen, også selv om det ikke kan indeholdes i traditionelle kategorier som objektivitet og subjektivitet, ramme og handling, sten og kød; snarere er det en ny slags virkelighed, der bliver til med storbyerne og deres menneskemasser: et netværk af bevægelser, der udviser en bemærkelsesværdig tendens til at antage genkendelige former i den vektorielle diagrammatisering, uanset hvem, der deltager i dem.

Den systemiske fremstilling beskriver ikke genstande på samme måde som den mekaniske fysik, elementære objekter, der kan anskues og manipuleres på forskellige måder, men etablerer sine genstande på et højere elementarniveau som gestalter med bestemte kvaliteter, der ikke nødvendigvis går igen på andre niveauer. Hermed bliver beskrivelsen af en by heller ikke tilnærmelser til et objekt $\mathrm{i}$ forskellige mulige indstillinger, men en række indstillinger, der hver tildanner deres systemiske objekt. Musils udgangspunkt er en skeptisk-rationalistisk antagelse af, at man ikke ved, hvad en by er: der findes ikke det rette perspektiv at beskrive byens »hvadhed« ud fra, men en række perspektiver med hver deres genstande, der som palimpsest-ark kan føjes til hinanden.

Disse perspektiver er bevidst fremmedartede: for det systemiske blik forvandler byen sig fra noget fortroligt til en futuristisk maskine, som er svær at genkende for hverdagslige bybrugere. Men på den anden side interesserer $\mathrm{Mu}-$ 
sil sig ikke bare for chok'et i fremmedgørelsen af det fortrolige, men fastholder samtidig, at det systemiske, der synes at bevæge sig langt væk fra fortroligheden, også befinder sig ganske tæt på en slags før-bevidst fortrolighedsniveau, - at enhver vil kunne genkende byen på dens gangart. Citatet ovenfor fortsætter således: »De to mennesker, der heri gik hen ad en bred, befærdet gade, havde naturligvis slet ikke det indtryk. De (...) vidste, hvem de var, og at de befandt sig på deres rette plads i en hoved- og residensstad.« Chok'et er således ikke alene fremmedhedens, men også genkendelsens chok: at en konsekvent fremstilling af det, vi oplever, bryder med de former, vi umiddelbart ville benytte til at formulere vores oplevelser. Den systemiske fremstillings intentionelle genstand er således, med Salman Rushdies smukke formulering, den synlige, men usete by.

Et andet eksempel på denne konvergens mellem det systemiske og bestemte sansemåder, der objektiveres i fremstillingen, kan være indledningen til kapitel 7 fra Joyces Ulysses (se appendiks). I de forste to små »afsnit« af denne tekst er der igen forskellige træk, som tilhører en systemisk orden. Det systemiske fremmanes direkte i placeringen af det konkrete sted i knudepunktet af to forskellige kort: på den ene side som centrum for sporvognenes bykort, på den anden side som distributionspunkt for den verdensomspændende postbesørgelse. Fremstillingen har udgangspunkt i et bestemt sted i Dublin, byens »hjerte«, men det fremstår netop ikke topografisk, men systemisk; stedet er vigtigt, fordi der herfra pumpes liv i form af transport- og kommunikationsmidler ud i bykortets arterielle system. På dette sted er byen nærværende in nucleo, en slags oversigtspunkt, der sammenfatter byen; men sammenfatningen omfatter ikke byen som sanselig, topografisk realitet: oversigten er alene systemisk (eller i hvert fald uden anden sanselighed end den let fetichistiske glæde ved alle de stednavne, der som drømmebøjer er forsamlet på ét sted; et motiv, der også er velkendt fra Proust). Byen er altså på en særlig måde både nærværende og fraværende i disse opremsninger; nærværende som en sum af systemelementer, fraværende som steder. Byens umiddelbare topografiske miljø optræder dislokeret, genindskrevet på et abstrakt kort. »Handlingen« på dette sted i romanen er dermed kontekstualiseret $i$ en systemformidlet bymæssighed; den nærværende aktivitet - flimren, råben, bevægelse - har det systemiske bykort som sin egentlige scene.

Denne dobbelthed, et nærvær i tid og rum, som er indskrevet på et dislokeret kort og dermed formidler noget nærværende og noget fraværende, noget umiddelbart sanseligt og noget systemformidlet, går igen i den handling, der udspiller sig videre $i$ uddraget, der foregår på en avisredaktion. Avisen, som afgiver det formelle mønster for passagen - de korte afsnit med prægnante overskrifter, som kan panorere diskontinuert over alskens forskelligartede em- 
ner - er netop karakteristisk ved at være ét stort dislokeret verdenskort, en collage af uforbundne virkelighedsfragmenter. Avisen har selv systemkarakter i organisationen af heterogene vidensfragmenter i en bestemt formidlingssammenhæng, som i kraft af den kontinuerte læsning anbringes i et sanseligt udvekslingsforhold. Fremstillingsmåden konsoliderer videre sammenf $\varnothing j n i n g e n$ af system og sansning gennem en række »ulogiske« koblinger, hvor det dislokerede kort modsvarer det dislokere(n)de medium, og mediets sanselighed tilsvarende modsvarer handlingens sanselige umiddelbarhed. Centrum for sammenkoblingen af disse to aspekter af system og sansning er formentlig de musikalsk dumptrumlende fade i tredje afsnit; de knytter an til det systemiske kort i det omfang de indskriver sig i en orden, der omfatter produktion, transport, varedistribution. Samtidig leverer de den nærværende st $\varnothing$ j, der dels polyfonisk vedbliver med at ledsage handlingens begivenheder, idet den fastholdes som en slags baggrundsst $\varnothing j$ gennem passagen, og dels fremmanes i sprogets rytmiske (og meningsløse) gentagelser, igen med mindelser, måske, til trykpressen.

Dette samlende »motiv«, hvis man kan kalde det sådan, synes da i næste omgang at danne mønster for det percept, som dannes af Brayden på vej op ad trappen: den automatagtige ryg, måske med mindelser til de arbejdende kuske, de fede folder, fed, fold, fed fold. Præsentationen af Braydens konkrete opdukken - $\mathrm{i}$ en »almindelig« roman havde vi været tilfredse med konstateringen: »i det samme kom Brayden op ad trappen... « eller lignende - skematiseres gennem en fremstillingsmåde, hvor sansningen er filtreret gennem den systemiske ordens nærvær. I et kort glimt făr vi et billede af en banal sanseerfaring, der har skolet sig i den systemiske orden, som erfaringen indgår i. Det understreges, at denne sansning er sœrlig; den varer kun et kort øjeblik inden passagen slutter med at opløse dette enestående percept i en sætning, som selv går i opløsning i blæsten og fortagsomheden: »...for at vinden kan. Ind. Ud.«

Det »besynderlige« billede af Brayden chokerer næppe læseren af Ulysses for så vidt det ikke er spor mere besynderligt end det meste af, hvad der står i denne roman; man ville for det meste formentlig notere, at billedet er typisk for Joyce - og derefter gå i gang med at fortolke det: alle de motiver og allusioner, der som altid hos Joyce er kulet ned i selv de mest uskyldige formuleringer. Læsningen af billedet i relation til den by-tematik og de spørgsmål om formidlingen mellem system og sansning, der har været på tale i det foregående, føjer ikke i egentlig forstand noget til sådanne fortolkninger. Til gengæld understreger den to andre aspekter af Joyces teknik. På den ene side knytter en sådan læsning sig til den umiddelbart æstetiske side af den litterære skrift, hvor interessen i mindre grad gælder opsporingen af en hermeneutisk dybdedimension i værket end en kortlægning af den sansning og de sansemåder, 
værket fremstiller. Og på den anden side kontekstualiseres denne æstetik, denne formning af sansningen, gennem fokuseringen på den urbane livsorganisering, der er baggrund for udkrystalliseringen af disse nye sansninger. Hos Joyce er det evident, hvordan den unikke sansning, der fremstilles i billedet af Brayden på vej op ad trappen, modsvarer bestemte aspekter af det systemiske urbane rum. Ved at knytte billedet af sansningen til et systemisk realitetslag, ophører den sansede by med blot at være bevidsthedens billede af en traditionel fænomenologisk genstand; bysansningen bliver i stedet en opfindelse af sansemåder, der modsvarer byens uanskuelige realitetsniveau.

Konfigurationen af system og sansning i de moderne byfortællinger rummer en dobbelt reformulering af byens virkelighedsindhold og sansningens billede. Den fænomenologiske grundholdning, der gennemsyrer det tyvende århundrede: det uomgængelige, naive spørgsmål om det problematiske forhold mellem den ydre verden, der byder sig til for mine sanser, og bevidsthedens bearbejdning heraf, stilles her på en insisterende, fremmedartet facon. Den fænomenologiske genstand mister sin evidente tingskarakter: det systemiske kan ikke »afbildes « i sammenhæng uden at overgå til en abstrakt, usanselig repræsentation, som det diagram, Musil optagner. Sansningens kobling hertil forbliver imidlertid nødvendigvis begrænset til det udsnit, som det kropslige sensorium kan omfatte. Derfor bliver den litterære bearbejdning af sansningens arbejde tvunget til at ops $\emptyset$ ge et komplement til den abstrakte repræsentation: sansemåder, der indoptager den systemiske abstraktion uden at forlade det kropslige sensoriums periferi: byen udstyres med en gangart, Braydens nakke med dumptrumlende fedtfolder.

Sansningen konstituerer altid et rum i mødet med sin genstand, og bogføringen af en sansning fremstiller et rumudsnit. I det omfang byfortællingen tilvirker et urbant realitetslag og sansemåder, der knytter sig hertil, omfatter den også konturerne af et særligt, urbant fiktionsrum. Hvilke rumlige træk kendetegner den synlige, men usete by? På den ene side har den bevaret den tredimensionale genstandslighed, som vores rumopfattelse er afhængig af. Men på den anden side er det, som om denne genstandslighed har mistet noget af sin aprioriske soliditet, gennemtrukket af andre realitetsaspekter, bevægelser og relationer, som ikke længere simpelt udspiller sig i rummet, men som først danner det. Måske en konstitution af rummet $\mathrm{i}$ tiden snarere end, som vi er vante til, af tiden i rummet, bevægelsen i »det faste kar«. Når byfortællingerne kan siges at indeholde en æstetisk formidlet refleksion over, hvad en by og dens rum overhovedet er for noget, kan det i denne sammenhæng have at gøre med, at sammenmonteringen af system og sansning skaber et rum, som er indlejret $i$ et andet, flygtigere element. ${ }^{11}$ 
Måske har ingen været tættere på at indfange karakteren af dette rum end Virginia Woolf. Et af hendes gennemkomponerede systempercepter følger den fornemt tillukkede bil, som passerer gennem Londons gader, mens Clarissa Dalloway køber blomster; efter at den første gang er dukket op følger fortælleren den over de næste fem-seks sider gennem gaderne i et flaubert'sk »survol«, der dykker ned i de indtryk og antagelser og associationer, som den på sin rute gennem byen afstedkommer forskellige steder i forskellige personer, hvilket skydes sammen til et kollektivt percept, en krusning i byens tekstur, måske en af de skygger, »som i drømme eller leg«, Musils heste taknemmeligt lod sig befri fra:

»Bilen var forsvundet, men den havde efterladt en let krusning, som flød gennem handskebutikker og hattebutikker og skrædderbutikker på begge sider af Bond Street. I tredive sekunder var alle hoveder vendt den samme vej - mod vinduet. Midt i valget af et par handsker - skulle de være hel- eller halvlange, citrongule eller lysegrå? - standsede damer op; da sætningen var sagt, var der sket noget. Noget, som var så ubetydeligt i sig selv, at intet måleapparat, selv om det var i stand til at registrere jordskælv i Kina, kunne opfange vibrationen; og dog var det i sin helhed mægtigt og i stand til at bevæge alles følelser; for i alle hattebutikkerne og skrædderbutikkerne så folk på hinanden og tænkte på de døde, på flaget, på Imperiet. I en pub i en sidegade var der en mand fra kolonierne, der fornærmede Huset Windsor, hvilket førte til ordvekslinger, knuste ølglas og almindelig tumult, som på den anden side af gaden gav sært genlyd i ørerne på de unge piger, som købte hvidt undertøj gennemtrukket med fine hvide bånd til deres bryllup. Den overfladekrusning, som bilen havde forårsaget, strejfede, efterhånden som den sank, noget meget dybtliggende. $\ll^{12}$ 


\section{Appendix}

James Joyce: Ulysses, dansk ovs. Mogens Boisen, 1980-udg., København: Gyldendal 1986, s. 144-145.

\section{I hjertet af den grønne ø’s metropolis}

Foran Nelsonsøjlen sagtnede sporvogne farten, rangerede, skiftede køretråd og afgik til Blackrock, Kingstown og Dalkey, Clonskea, Rathgar og Terenure, Palmerston Park og Upper Rathmines, Sandymount Green, Rathmines, Ringsend og Sandymount Tower, Harold's Cross. Den hæse trafikvagt fra Dublin United Tramway Company råbte til afgang:

- Rathgar og Terenure!

- Kom så, Sandymount Green!

Til højre og venstre kørte en dobbeltdækker og en éndækker side om side med skramlen og klingrende klokker frem fra deres endespor, svingede ind på linien indefter og gled afsted på parallelle kurser.

- Afgang, Palmerston Park!

\section{Kronens bærer}

Under indgangspartiet til hovedpostkontoret råbte og pudsede skopudsere. Kørt frem i North Prince's Street modtog Hans Majestæts zinnoberrøde postvogne, der på siderne bar de kongelige initialer, E. R., de med høje råb nedkastede sække med breve, prospektkort, brevkort, pakker, anbefalede og frankerede, til lokal, mellembys, indenlandsk og oversøisk befordring.

\section{De herrer af pressen}

Tungtbest $\varnothing$ vlede kuske rullede dumptrumlende fade ud fra Prince's lager og bumpede dem op på bryggervognen. På bryggervognen bumpedes dumptrumlende fade af tungtbestøvlede kuske fra Prince’s lager.

- Dér står det, sagde Red Murray. Alexander Keyes.

- Vær rar og klip det ud, sagde Mr. Bloom, så skal jeg tage det med hen på Telegraph's redaktion.

Atter knirkede døren til Ruttledges kontor. Davy Stephens, meget lille i sin store slængkappe og med en lille filthat over sine lokker, gik ud med en rulle papirer under frakken, en kongens kurér.

Red Murrays lange saks skar med fire sikre snit annoncen ud af avisen. Saks og klister. 
- Jeg går gennem trykkeriet, sagde Mr. Bloom og tog den udklippede firkant.

- Hvis han ønsker det, kan vi jo lave en notits til ham, sagde Red Murray alvorligt med penneskaftet bag $\emptyset$ ret.

- Godt, sagde Mr. Bloom og nikkede, det skal jeg ordne.

Vi.

William Brayden,

Esquire, fra Oaklands, Sandymount

R'ed Murray pirkede med saksen til Mr. Blooms arm og hviskede:

- Brayden.

Mr. Bloom vendte sig om og så den liberiklædte dørvogter løfte sin bogstavprydede hat, da en statelig skikkelse trådte ind mellem opslagstavlerne for Weekly Freeman and National Press og Freemann's Journal and National Press. Dumptrumlende Guinness-fade. Stateligt gik den op ad trappen, en paraply styrede dens skridt, dens ansigt var højtideligt og indrammet af skæg. Den sortklædesklædte ryg steg op ad hvert trin: ryg. Hele hans hjerne sidder i nakken, siger Simon Dedalus. Fedtfolder bagpå. Fede nakkefolder, fed, fold, fed, fold.

- Synes De ikke, at hans ansigt ligner Vor Frelsers? hviskede Red Murray.

- liicrii, hviskede døren til Ruttledges kontor. Man anbringer altid den ene $\mathrm{d} \emptyset \mathrm{r}$ lige over for den anden, for at vinden kan. Ind. Ud. 


\section{Noter}

1. Se Franco Moretti: Opera mundi, Milano 1993.

2. Raymond Williams: The Country and the City, London 1973, s. $356 \mathrm{f}$.

3. Volker Klotz: Die erzählte Stadt, München 1969, s. 439.

4. Se Klaus R. Scherpe: »Von der erzählten Stadt zur Stadterzählung «, in Jürgen Fohrmann und Harro Müller (Hrsg.): Diskurstheorien und Literaturwissenschaft, Frankfurt/M. 1988, s. 421 f.

5. Michel de Certeau: L'invention du quotidien. Tome 1. Arts de faire, Paris 1990 (org. 1980), kap. 9.

6. Jean-Paul Sartre: Situations II, Paris 1948, s. $89 \mathrm{ff}$.

7. Gilles Deleuze \& Félix Guattari: Qu'est-ce que la philosophie?, Paris 1991, s. 158.

8. Til denne diskussion, se Alain Lhomme: »La fabrique de la ville«, in Les cahiers de la philosophie 17, Paris 1993.

9. Alfred Döblin: Berlin Alexanderplatz (da. overs. Johannes Weltzer og Ulrich Knigge), København 1981.

10. Robert Musil: Manden uden egenskaber (da. overs. Karsten Sand Iversen), bind 1, København 1994, s. 189 f.

11. Dette spørgsmål om byrummets element i den litterære tekst har jeg behandlet mere udførligt i artiklen »Byen, teksten og rummet« i Lise Bek (red.): Perspektivet og dets alternativer, Aarhus 1977 (i.p.)

12. Virginia Woolf: Mrs. Dalloway (da. overs. Jørgen Christian Hansen; her let modificeret), København 1984, s. 21. 